\title{
ECLOGITES FROM THE GRIB KIMBERLITE PIPE, ARKHANGELSK, RUSSIA
}

\author{
Vladimir Malkovets ${ }^{1,2,3}$, Lawrence Taylor ${ }^{2}$, William Griffin ${ }^{3}$, Suzanne O'Reilly ${ }^{3}$, Nikolai \\ Pokhilenko $^{1}$, Elisei Verichev ${ }^{4}$, Nikolai Golovin ${ }^{5}$, Konstantin Litasov ${ }^{6}$, John Valley ${ }^{7}$ and Michael \\ Spicuzza $^{7}$ \\ ${ }^{1}$ Institute of Mineralogy and Petrography SB RAS, Russia $;{ }^{2}$ Planetary Geoscience Institute, University of Tennessee, USA; \\ ${ }^{3}$ GEMOC National Key Centre, School of Earth Sciences, Macquarie University, Australia; ${ }^{4}$ Arkhangelskgeolrazvedka Ltd, \\ Russia; ${ }^{5}$ Arkhangelskgeoldobycha Ltd, Russia; 6 Institute of Mineralogy, Petrology and Economic Geology, Tohoku
}

University, Japan; 7 University of Wisconcin, Madison,USA

\section{INTRODUCTION}

Eclogite xenoliths in kimberlites and alkali basalts are of great scientific interest because they can provide information on the chemistry, mineralogy, and petrology of the mantle, as well as on the evolutionary history and interaction between the mantle and the crust. The origins of such eclogitic nodules have been actively discussed for more than 30 years. However, it is now generally agreed that the majority of the mantle eclogites had their ultimate origin from precursors in the ancient crust. That is, they are the products of subduction of oceanic crust beneath a craton, associated with devolitalization and possible partial melting. Nevertheless, much remains to be unraveled concerning such a complicated scenario. In this paper, we apply the results of our study of eclogitic xenoliths from the newly discovered Middle Paleozoic diamondiferous kimberlite pipe, Grib, in the Arkhangelsk Province of Russia.

\section{GEOLOGY OF THE ARKHANGELSK REGION}

The East European Platform, a collage of Archaean cratons and Early Proterozoic mobile belts, underlies most of western Russia and the Baltic states. Riphean to Paleozoic sediments cover most of the platform to the south and east of Scandinavia. In its eastern part, there are two Archean cratons, Kola and Karelis, separated by the Early Proterozoic Belomorian mobile belt.

The small-volume Arkhangelsk igneous activity is mostly in the form of sub-volcanic pipes (diatremes), together with some sills and dikes (Sinitsin \& Grib, 1995). Clusters of diatremes form several igneous fields (Fig. 1), each with distinctive petrological characteristics. The fields occur in two groups on the SE side of the White Sea: 1) along and up to $100 \mathrm{~km}$ inland from the Zimniy Bereg (i.e. Winter Coast); and 2) on the NE side of the Onega Peninsula, separated from the Zimniy Bereg by the Gulf of Dvina. A short, intense, and spread phase of Late Devonian ( $\sim 380-360$ Ma) mafic, alkaline-ultramafic, and carbonatitic magmatism, immediately followed by large-scale lithospheric doming of the East European Platform (Mahotkin et al., 2000).

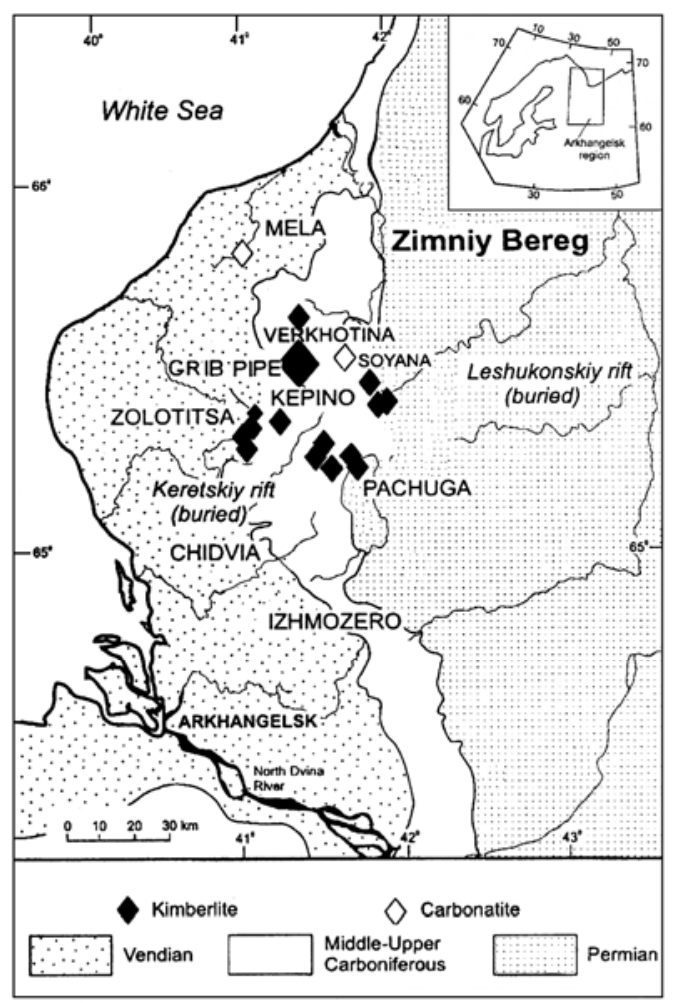

Figure 1: Simplified geological sketch map of the Arkhangelsk Alkaline Igneous Province (Mahotkin et al., 2000). 
The Late Devonian magmatism of the Kola region forms one of the largest intrusive and subvolcanicalkaline provinces in the world. The Kola Alkaline Province outcrops over an area of $\sim 100,000$ $\mathrm{km}^{2}$ and is comprised of 24 igneous complexes (Kogarko et al., 1995; Mahotkin et al., 2000).

Kimberlites are the predominant feature in the Zolotitsa and Mela fields, and a component of the KepinoPachuga and Verkhotina-Soyana fields. They can be divided geographically (Fig. 1) into a predominantly mica-poor, Eastern Group and a predominantly micaceous, Western Group, superficially similar to Group I and Group II South African kimberlites, respectively (Parsadanyan et al., 1996). The discovery in 1996 of the richly diamondiferous Grib kimberlite pipe (also known as Anomaly 441) terminated the longestablished notion (e.g., Sablukova et al., 1995) that only the Western Group kimberlites are potentially economic (Verichev et al., 1998).

\section{PETROGRAHY}

Eclogites from Grib pipe are composed of dark-tobright green clinopyroxene up to $3 \mathrm{~cm}$ and pale orangish-pink garnet up to $1.3 \mathrm{~cm}$. Two of three eclogites of Group A contain phlogopite in apparent textural equilibrium with the clinopyroxene and garnet. Trace amounts of sulfide occur in some of the samples. The xenoliths are highly fractured, with moderate secondary alteration, including serpentine, chlorite, and carbonate. Kimberlite penetrates fractures in the most of the samples to various degrees. These is evidence for a late-stage partial-melting event in each sample (Spetsius and Taylor, 2002).

\section{MINERALOGICAL AND GEOCHEMICAL CHARACTERISTICS}

\section{MAJOR ELEMENTS}

The chemistries of the primary phases of the Grib eclogites are presented in Tables 1 and 2 . Compositional data on coexisting garnet and clinopyroxene show that the xenoliths are classified as Group A and B eclogites, based upon the classification scheme of Taylor and Neal (1989) (Fig. 2.).

Garnets in these eclogite samples are homogeneous, within individual samples. Garnets from three eclogite samples are $\mathrm{MgO}$-rich, with a pyrope component of 75 to $78 \%$. These garnets contain higher $\mathrm{Cr}_{2} \mathrm{O}_{3}(0.18$ to $0.73 \%$; Table 1) and lower $\mathrm{CaO}$ (4.02 to 5.68\%) than the other garnets and plot in the Group A eclogite range (as per Shervais et al., 1988) on a pyrope-grossular almandine+spessartine plot. Garnets from four other eclogite samples have lower $\mathrm{MgO}$ (43.2 to $60.2 \%$ pyrope) and average $\mathrm{Cr}_{2} \mathrm{O}_{3}(0.06$ to $0.35 \%)$, has higher $\mathrm{CaO}(5.73$ to $11.74 \%)$, and plot in the Group B eclogite range.

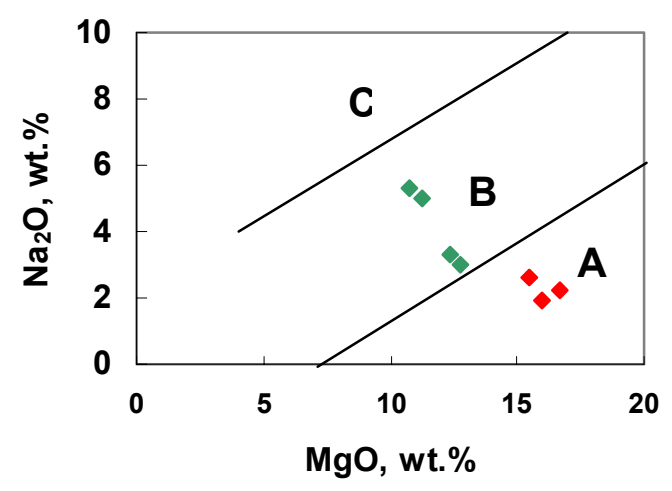

Figure 2: $\mathrm{MgO}$ vs. $\mathrm{Na}_{2} \mathrm{O}$ in clinopyroxene.

Table 1: Composition of garnets

\begin{tabular}{|c|c|c|c|c|}
\hline Sample & $441 / 3$ & $93 / 265$ & $79 / 197$ & $94 / 210$ \\
\hline $\mathrm{SiO}_{2}$ & 40.3 & 39.3 & 41.7 & 41.9 \\
\hline $\mathrm{TiO}_{2}$ & 0.68 & 0.33 & 0.41 & 0.22 \\
\hline $\mathrm{Al}_{2} \mathrm{O}_{3}$ & 21.5 & 21.1 & 22.7 & 23.3 \\
\hline $\mathrm{Cr}_{2} \mathrm{O}_{3}$ & 0.53 & 0.06 & 0.41 & 0.18 \\
\hline $\mathrm{FeO}$ & 17.4 & 17.8 & 11.4 & 10.2 \\
\hline $\mathrm{MnO}$ & 0.28 & 0.42 & 0.38 & 0.33 \\
\hline $\mathrm{MgO}$ & 12.8 & 8.44 & 18.51 & 20.6 \\
\hline $\mathrm{CaO}$ & 7.03 & 11.7 & 5.01 & 4.02 \\
\hline $\mathrm{Na}_{2} \mathrm{O}$ & 0.24 & 0.06 & 0.08 & 0.05 \\
\hline Total & 100.8 & 99.3 & 100.56 & 100.9 \\
\hline
\end{tabular}

Table 2: Composition of clinopyroxenes

\begin{tabular}{|c|c|c|c|c|}
\hline Sample & $441 / 3$ & $93 / 265$ & $79 / 197$ & $94 / 210$ \\
\hline $\mathrm{SiO}_{2}$ & 54.9 & 53.8 & 54.9 & 54.9 \\
\hline $\mathrm{TiO}_{2}$ & 0.61 & 0.22 & 0.35 & 0.13 \\
\hline $\mathrm{Al}_{2} \mathrm{O}_{3}$ & 6.95 & 4.53 & 3.12 & 2.92 \\
\hline $\mathrm{Cr}_{2} \mathrm{O}_{3}$ & 0.31 & 0 & 0.39 & 0.06 \\
\hline $\mathrm{FeO}$ & 6.38 & 5.89 & 3.83 & 3.42 \\
\hline $\mathrm{MnO}$ & 0.02 & 0.03 & 0.12 & 0.03 \\
\hline $\mathrm{MgO}$ & 10.8 & 12.7 & 15.4 & 16.5 \\
\hline $\mathrm{CaO}$ & 14.6 & 19.6 & 19.3 & 19.6 \\
\hline $\mathrm{Na}_{2} \mathrm{O}$ & 5.31 & 3.05 & 2.6 & 2.28 \\
\hline $\mathrm{NiO}$ & 0 & 0 & 0.1 & 0.1 \\
\hline Total & 99.99 & 99.88 & 100.1 & 99.89 \\
\hline
\end{tabular}


Clinopyroxenes in these eclogites are heterogeneous, especially for $\mathrm{Al}_{2} \mathrm{O}_{3}$ and $\mathrm{Cr}_{2} \mathrm{O}_{3}$. Clinopyroxenes in 79/197, 94/210 and 102/236 samples contain higher $\mathrm{MgO}$ (15.4 to $16.5 \%$ ) and average $\mathrm{Cr}_{2} \mathrm{O}_{3} \quad(0.16$ to $0.39 \%)$ and lower $\mathrm{Al}_{2} \mathrm{O}_{3}(2.43$ to $3.12 \%)$ and $\mathrm{Na}_{2} \mathrm{O}$ ( 1.73 to $2.61 \%$ ) compared to other samples and plot in the Group-A range on an $\mathrm{MgO}-\mathrm{Na}_{2} \mathrm{O}$ plot (Fig. 2; Table 2).

\section{P-T ESTIMATION}

The chemical compositions of coexisting minerals are useful in determining equilibrium temperatures. Coexisting garnet and pyroxene geothermometry (Ellis and Green, 1979) was applied to estimate the equilibrium temperatures at various assumed pressures, i.e., 40, 50, and $60 \mathrm{kbar}$. Group B eclogites provide higher estimated temperatures $\left(775-1025{ }^{\circ} \mathrm{C}\right)$, compared with Group A eclogites $\left(715-870{ }^{0} \mathrm{C}\right)$, for a pressure of $50 \mathrm{kbar}$. The results of the temperature estimates are shown in Table 3.

\section{Table 3: Results of T estimations}

$\begin{array}{lllll}\text { Sample } & 40 \mathrm{~kb} & 50 \mathrm{~kb} & 60 \mathrm{~kb} & \text { Group } \\ & & & & \\ 79 / 197 & 710 & 735 & 765 & \mathrm{~A} \\ 94 / 210 & 695 & 715 & 735 & \mathrm{~A} \\ 102 / 236 & 840 & 870 & 900 & \mathrm{~A} \\ 73 / 230 & 985 & 1025 & 1055 & \mathrm{~B} \\ 93 / 265 & 750 & 770 & 795 & \mathrm{~B} \\ 102 / 254.5 & 770 & 795 & 820 & \mathrm{~B} \\ 441 / 3 & 955 & 990 & 1020 & \mathrm{~B}\end{array}$

\section{TRACE ELEMENTS}

Trace-element analyses of garnet, clinopyroxene, and phlogopite were made in-situ in polished thick sections, with LA-ICP-MS at the GEMOC National Key Centre, Macquarie University, Australia. Methods and operating conditions have been described by Norman et al., 1996. All clinopyroxenes are characterized by convex-upward REE patterns (chondrite-normalized), with significant variations in the trace-element concentrations. Chondrite-normalized La values $\left(\mathrm{La}_{\mathrm{n}}\right)$ and $\mathrm{La} / \mathrm{Yb}$ ratios are 3.5-24.3 and 5.4-139 for the Group A clinopyroxenes and 0.9-13.7 and 0.7-18.7, resp., for the Group B clinopyroxenes. The garnets of the Grib eclogites display a wide range of HREE abundances (e.g., $\mathrm{Lu}_{\mathrm{n}}=6.22-29.64$ ). $\mathrm{La}_{\mathrm{n}}$ and $\mathrm{La} / \mathrm{Yb}$ ratios for the garnets are 6.2-29.6 and 0.003-0.019 for Group A and 9.5-16.3 and 0.003-0.012 for Group $\mathrm{B}$, resp. $\mathrm{Gd} / \mathrm{Yb}$ ratios in garnets are in a range of $0.24-0.87$, with an average of 0.53 . None of the clinopyroxenes or garnets showed any $\mathrm{Eu}$ anomaly. Distributions of trace elements in garnets and clinopyroxenes are relatively uniform, with the exception of one Group A eclogite, which contains two types of clinopyroxene having different LREE and MREE abundances. These two Cpx types have $\mathrm{La}_{\mathrm{n}}$ and $\mathrm{La} / \mathrm{Dy}$ ratios 2.95 vs. 1.99 and 15.6 vs. 11.48 , respectively.
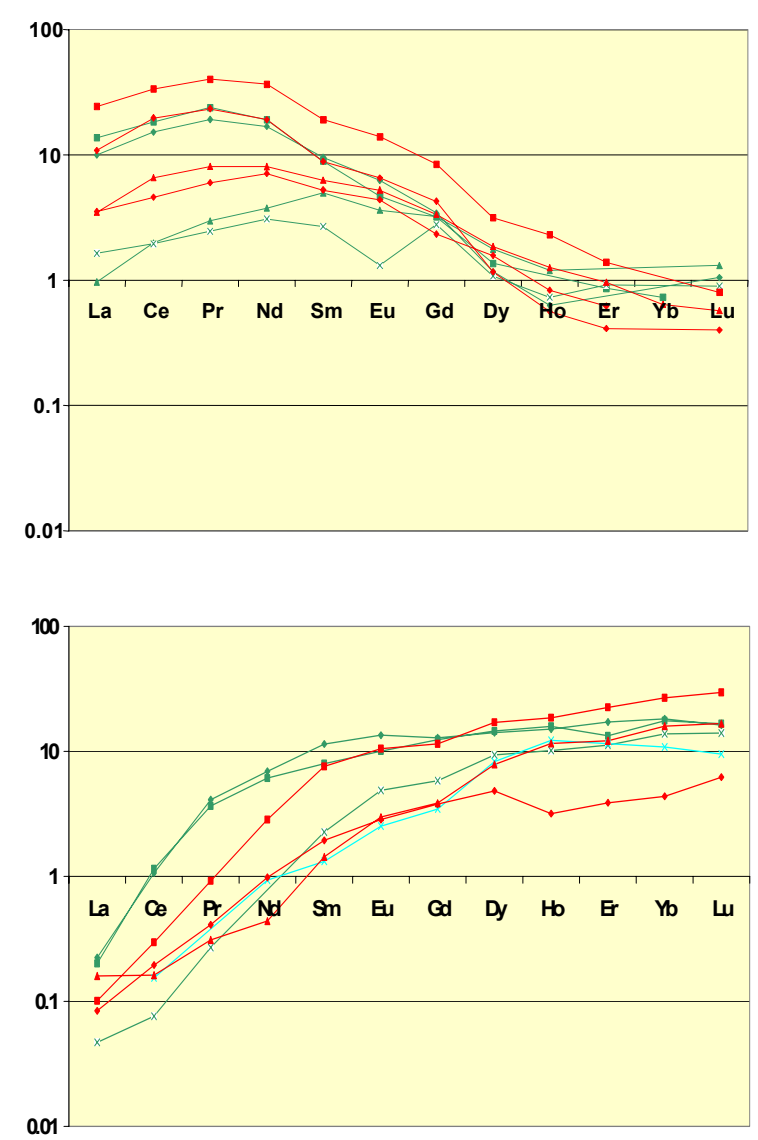

Figure 3: REE patterns of clinopyroxenes (top) and garnets (bottom) in the Grib pipe eclogites. Group A red data points, Group B - green data points.

\section{OXYGEN ISOTOPES}

Clean mineral separates were prepared of garnets from 7 of the eclogite samples and oxygen isotopes were determined by the laser-fluorination technique at the University of Wisconsin, using the methodology presented in Spicuzza et al. (1998). Garnets were analyzed because they are the freshest phase in the Grib eclogites. Values of $\delta^{18} \mathrm{O}$ values of the garnets range between 4.05 and $5.64 \%$ (Figure 3, Table 4). The high $\mathrm{MgO}$ garnets of Group $\mathrm{A}$ have a restricted range of $\delta^{18} \mathrm{O}$ values (5.4 to $5.64 \%$ ) and lie within the mantle 
range of $5.4 \pm 0.4 \%$ (Mattey et al., 1994). The low$\mathrm{MgO}$ garnets have a broader range of isotopic and major-element compositions. Except for sample 73/230, all garnets of the Group B eclogite have a restricted range of $\delta^{18} \mathrm{O}$ values of 4.05 to $4.29 \%$, well below the mantle range. Garnet $73 / 230$ has $\delta^{18} \mathrm{O}$ value of $5.4 \%$ ) comparable with values of garnets of the Group A eclogites. The values of $\delta^{18} \mathrm{O}$ show a good correlation with other elements (e.g., $\mathrm{MgO}, \mathrm{CaO}$ ) of garnet as reported for Siberian eclogite xenoliths (Jacob et al., 1994; Snyder et al., 1997).

\section{Table 4: Garnet compositions and $O$ isotopes data}

$\begin{array}{lllll}\text { Sample } & \text { Pyr } & \text { Alm } & \text { Gross } & \delta^{18} \mathrm{O} \\ & & & & \\ 79 / 197 & 65.2 & 20.9 & 10.1 & 5.64 \\ 94 / 210 & 70.6 & 18.6 & 7.6 & 5.64 \\ 102 / 236 & 63 & 21.1 & 12 & 5.4 \\ 73 / 230 & 50.1 & 33.9 & 15.2 & 5.4 \\ 93 / 265 & 31.8 & 35.2 & 27.3 & 4.27 \\ 102 / 254.529 .9 & 38 & 27.9 & 4.29 \\ 441 / 3 & 46.4 & 33.6 & 13.5 & 4.05\end{array}$

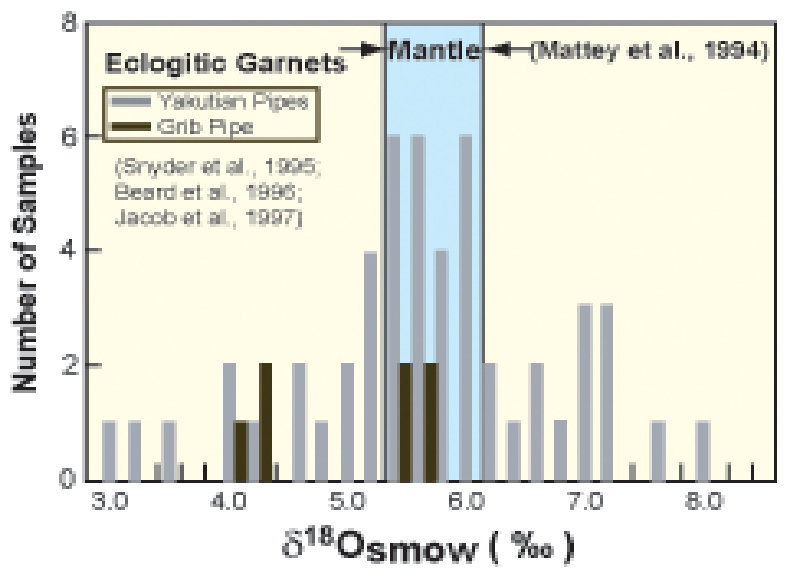

Figure 4: Oxygen isotope values for eclogitic garnets from Yakutian kimberlite pipes versus those from the Grib pipe. Note the two sets of values for the Grib garnets, which distinguish the Group A (mantle values) versus the Group B lower values.

\section{DISCUSSION}

Based upon modal and mineral compositions, the seven Grib pipe eclogites in this study were assigned to two eclogite groups: Group A (three samples) and Group B (four samples). Group A eclogites are phlogopite- bearing; their constituent minerals have high $\mathrm{Mg \#}$ and $\mathrm{Cr}_{2} \mathrm{O}_{3}$ content, and clinopyroxenes in this group have low-jadeite component. The geochemical features of Group A eclogites resemble those of garnet pyroxenites. They are believed to be the product of high-pressure fractionates from alkaline basaltic melt in the upper mantle. Values of $\delta^{18} \mathrm{O}$ of garnet separates from these eclogites are all within the mantle range. There is no evidence to indicate that these Group A eclogites were derived from crustal materials.

Group $\mathrm{B}$ eclogites have higher contents of $\mathrm{Al}_{2} \mathrm{O}_{3}$ and $\mathrm{FeO}$ and lower $\mathrm{MgO}$ and $\mathrm{Cr}_{2} \mathrm{O}_{3}$. The Group $\mathrm{B}$ eclogites are thought to be the metamorphic relicts of subducted oceanic crust (Taylor and Neal, 1989; Qi et al., 1994). The most compelling evidence for a crustal origin of eclogite xenoliths are stable isotope compositions that deviate from established peridotitic values, i.e., $\delta^{18} \mathrm{O}$ values that lie beyond $5.5 \pm 0.4 \%$ (e.g., MacGregor and Manton, 1986; Jacob et al., 1994). Eclogites with high and low $\delta^{18} \mathrm{O}$ values are believed to have obtained their isotopic compositions through low- and hightemperature seawater alteration prior to subduction (Gregory and Taylor, 1981).

Group A eclogites, worldwide, have oxygen values mostly within the mantle range. However, several Group A eclogites have been reported with values distinctly outside mantle, raising the question of crustal protoliths even for these eclogites (Viljoen, 1994; Taylor et al., 2003). However, among eclogite suites from the same pipe, Group A eclogites usually do not define the lowest values (Snyder et al., 1998). The observed oxygen isotopes of the Grib high $\mathrm{MgO}$ eclogites show mantle-like $\delta^{18} \mathrm{O}$, indicating either a mantle origin or possibly oceanic crust with mantle (=MORB) oxygen values. The restricted range of compositions and high $\mathrm{MgO}, \mathrm{NiO}$, and $\mathrm{Cr}_{2} \mathrm{O}_{3}$ contents support an intra-mantle origin for these samples. In contrast, the broader range of $\delta^{18} \mathrm{O}$ of the low-MgO, Group B eclogites is a signature of an oceanic crystal protolith.

\section{REFERENCES}

Ellis, D.J., Green, D.H., 1979. An experimental study of effect of $\mathrm{Ca}$ upon garnet-clinopyroxene $\mathrm{Fe}-\mathrm{Mg}$ exchange equilibria. Contrib. Mineral. Petrol. 71, 1322.

Gregory, R.T., Taylor, Jr., 1981. An oxygen isotope profile in a section of Cretaceous oceanic crust, Samail ophiolite, Oman: Evidence for ${ }^{18} \mathrm{O}$ buffering of the oceans by deep $(>5 \mathrm{~km})$ seawater-hydrothermal circulation at mid-ocean ridges. Jour. Geophys. Res. 86, 2737-2755.

Jacob, D., Jagoutz, E., Lowry, D., Mattey, D., Kudrjavtseva, G., 1994. Diamondiferous eclogites from Siberia: 
Remnants of Archean oceanic crust. Geochim. Cosmochim. Acta. 58, 5195-5207.

Kogarko, L.N., Kononova, V.A., Orlova, M.P., Woolley. A.P., 1995. Alkaline Rocks and Carbonatites of the World: Part 2: Former USSR. Chapman\&Hall, London.

MacGregor, I.D., Manton, W.I., 1986. Roberts Victor eclogites: ancient oceanic crust. J. Geophys. Res. 91, 14,063-14,079.

Mahotkin, I.L., Gibson, S.A., Thompson, R.N., Zhuravlev, D.Z., Zherdev P.U., 2000. Late Devonian diamondiferous kimberlite and alkaline picrite (protokimberlite?) magmatism in the Arkhangelsk region, NW Russia. Jour. of Petrol. 41, 201-227.

Mattey, D., Lowry, D., Macpherson, C., 1994. Oxygen isotope composition of mantle peridotite. Earth Planet. Sci. Lett. 128, 231-241.

Norman, M.D., Pearson, N.J., Sharma, A.,Griffin, W.L., 1996. Quantitative analysis of trace elements in geological materials by laser ablation ICPMS: instrumental operating conditions and calibration values of NIST glasses. Geostand. Newsl. 20, 247261.

Parsadanyan, K.S., Kononova, V.A., Bogatikov, O.A., 1996. Sources of heterogeneous magmatism of the Arkhangelsk diamondiferous province. Petrology. 4, 460-479.

Qi, Q., Taylor, L.A., Snyder, G.A., Sobolev, N.V., 1994. Eclogites from the Obnazhennaya kimberlite pipe, Yakutia, Russia. Inter. Geol. Rev. 36, 911-924.

Sablukova, L.I., Sablukov, S., Griffin. W.L., O’Reilly, S.Y., Ryan, C.G., Win, T.T., Grib, V., 1995. Lithosphere evolution in the Arkhangelsk kimberlite province. Ext. Abstr. $6^{\text {th }}$ Int. Kimb. Conf. Novosibirsk, Russia, pp. 487-489.

Shervais, J.S., Taylor, L.A., Lugmair, G.W., Clayton, R.N., Mayeda, K., Deines, P., Rossman, G.R., Sobolev, N.V., 1988. Archean oceanic crust and the evolution of sub-continental mantle: Eclogites from Southern Africa. Geol. Soc. Amer. Bull. 100, 411-423.

Sinitsin, A.V., Grib, V.P., 1995. Arkhangelsk kimberlite province: field guidebook. $6^{\text {th }}$ Int. Kimb. Conf. Novosibirsk, Russia.

Snyder, G.A., Keller, R.A., Taylor, L.A., Remley, D., Halliday, A.N., Sobolev, N.V., 1998. The origin of ultramafic (Group A) eclogites: $\mathrm{Nd} \& \mathrm{Sr}$ isotopic evidence from the Obnazhennaya kimberlite, Yakutia. Ext. Abstr. $7^{\text {th }}$ Int. Kimb. Conf. Cape Town, South Africa, pp. 823-825.

Snyder, G.A., Taylor, L.A., Crozaz, G., Halliday, A.N., Beard, B.L., Sobolev, V.N., Sobolev, N.V., 1997. The origins of Yakutian eclogite xenoliths: Jour. Petrol. $38,85-113$.

Spetsius, Z.V., and Taylor, L.A., 2002, Partial melting in mantle eclogite xenoliths: Clues to microdiamond genesis. International Geology Review. 44, 973-987.

Spicuzza, M.J., Valley, J.W., Kohn, M.J., Girand, J.P., and Fouillac, A.M., 1998. The rapid heating, defocused beam technique: A CO2-laser-based method for highly precise and accurate determination of $\delta 18 \mathrm{O}$ values of quartz. Chem. Geol. 144, 195-203.
Taylor, L.A., Neal, C.R., 1989. Eclogites with oceanic crustal and mantle signatures from the Bellsbank kimberlite, South Africa, part I: Mineralogy, petrography, and whole rock chemistry. J. Geol. 97, 551-567.

Taylor, L.A., Snyder, G. A., Keller, R., Remley, D. A., Anand, M., Wiesli, R., Valley, J., Kurosawa, M., and Sobolev, N. V., 2003. Petrogenesis of group A eclogites and websterites: Evidence from the Obnazhennaya kimberlite, Yakutia. Contr. Mineral. Petro., in press.

Verichev, E.M., Sablukov, S.M., Sablukova, L.I., Zhuravlev, D.Z., 1998. A new type of diamondiferous kimberlite of the Zimniy Bereg area (pipe named after Vladimir Grib). Ext. Abstr. $7^{\text {th }}$ Int. Kimb. Conf. Cape Town, South Africa, pp. 940-942.

Viljoen, K.S., 1994. The petrology and geochemistry of a suite of mantle-derived eclogite xenoliths from the Kaalvallei kimberlite, South Africa. Ph.D. Thesis, Univ. Witwatersrand, Johanesburg, South Africa.

Contact: Vlad Malkovets, Planetary Geosciences Institute, Department of Earth and Planetary Sciences, University of Tennessee, Knoxville, TN, 37996-1410, USA, E-mail: vomal@uiggm.nsc.ru 